\title{
Comparative study of the blinking time between young adult and adult video display terminal users in indoor environment
}

\author{
Estudo comparativo do tempo de piscadas entre adultos jovens e adultos \\ usuários de monitor de microcomputador em ambiente climatizado
}

Tânia Mara Cunha Schaefer ${ }^{1}$ Arthur Rubens Cunha Schaefer ${ }^{2}$ Fernando Cesar $\mathrm{Abib}^{3}$ Newton Kara José ${ }^{4}$
Trabalho realizado na Universidade Federal do Paraná - UFPR - Curitiba (PR) - Brazil.

${ }^{1}$ Postgraduated in Ophthalmology at Universidade de São Paulo - USP - São Paulo (SP) - Brazil.

${ }^{2}$ Ophthalmologist and Fellow of the Ophthalmology Service at USP - São Paulo (SP); Fellow of the Ophthalmology Service at Santa Casa de Misericórdia de São Paulo - São Paulo (SP) - Brazil.

${ }^{3}$ Doctor in Ophthalmology, Professor of Anatomy Department at UFPR - Curitiba (PR) - Brazil.

${ }^{4}$ Doctor in Ophthalmology, Professor of Ophthalmology at USP - São Paulo (SP) - Brazil.

Correspondence address: Tânia Mara Cunha Schaefer. Av. Getulio Vargas, 2.932, $8^{\circ}$ andar - Curitiba (PR) - Brazil CEP 80240-040

E-mail: tania@schaefer.com.br

Recebido para publicação em 07.05.2009

Última versão recebida em 23.09.2009

Aprovação em 05.10.2009

\section{RESUMO}

Objective: Investigate the average blinking time in conversation and in Video Display Terminal use of young adults and adults in the presbyopic age group. Methods: A transversal analytical study in a readily accessible sample consisting of Volkswagen do Brasil - Curitiba, Paraná employees was performed. The cohort group consisted of 108 subjects divided into two age groups: Group 1, the young adult group (age range 20-39): 77 employees, mean age of 30.09 \pm 5.09 ; Group 2, the presbyopic adult group, (age range 40-53): 31 employees, mean age of 44.17 \pm 3.00 . Subjects under 18 years of age, with a history of ocular disorders, contact lens wearers and computer non-users were excluded. The subjects had their faces filmed for 10 minutes in conversation and VDT reading. Student's $t$-test was used and the statistical significance level was 95\%. Results: The average time between blinks in Group 1 for conversation and VDT reading was $5.16 \pm 1.83$ and $10.42 \pm 7.78$ seconds, respectively; in Group 2. $4.90 \pm 1.49$ and $10.46 \pm 5.54$ seconds. In both age groups, the time between blinks in VDT reading situations was higher $(\mathrm{p}<0.0001)$. There was no statistically meaningful difference for conversation and VDT reading situations when the two studied age groups were compared ( $p>0.05)$. Conclusion: There was an increase in the blinking time between young adults and the presbyopic group in VDT use situations when compared with reading situations. The difference in the blinking frequency between young adults and the presbyopic group in VDT use and reading situations was not statistically significant.

Keywords: Computer terminals/utilization; Blinking/physiology; Presbyopia; Adolescent; Adult

\section{INTRODUCTION}

Blinking is responsible for tear distribution on the ocular surface and contributes to maintain corneal and conjunctive integrity. After blinking, it takes the tear a second to distribute evenly and acquire its characteristic aspect, where mucins are in contact with the corneal epithelial surface, the lipid phase in contact with the air and the aqueous phase between these two layers ${ }^{(1)}$.

The tear film protects the surface of the eye from environmental factors and minimizes damages caused by corneal exposure. Each animal species has its own blink pattern, which is believed to be related to the time the tear 
film remains intact. In the case of humans, the average eyeblink rate is 3 to 25 times per minute ${ }^{(2)}$.

Involuntary blinking takes place spontaneously and voluntary blinking depends on the individual's control. Furthermore, voluntary blinking is divided into spontaneous, which takes place at constant intervals, and reflex, resultant from an external corneal stimulus ${ }^{(3)}$. Involuntary blinking lasts from 290 to 750 milliseconds. It is influenced by several conditions, among them the environmental lighting, temperature, air draught speed, ocular pathologies, and attention levels ${ }^{(4)}$.

Blinking is said to be complete when the eyelid closes completely and conceals the ocular bulb; on the other hand, blinking is said to be incomplete when eyelid closure is partial $^{(5-6)}$. Blink rate may be affected by some ocular surface changes, ocular diseases, sexual activities, attention levels, and other conditions such as lighting, temperature, airflow and work-related factors ${ }^{(7-10)}$.

Absence of blinking or a blink rate decrease may lead to the rupture of the tear film and cause discomfort, eye strain, burning sensation, excessive lacrimation, willingness to keep the eyes closed, pain, keratitis, visual alterations and decrease in vision capability.

The use of the computer to perform routine tasks has led to behavioral and organic changes in its users, who often complain about visual discomfort, asthenopia-induced conditions and functional dry eye syndrome, which directly interfere in their life quality and productivity ${ }^{(11-12)}$.

For the Committee on Work and Vision of the International Commission of Occupational Health (ICOH ICWC) ${ }^{(13)}$, the most frequent alterations reported include blurred vision, double vision, visual discomfort, contact-lens-induced visual problems, burning sensation, gritty sensation, lacrimal film disorders, retrobulbar and periorbital pain, conjunctival hyperemia, and contact lens discomfort. Other symptoms reported were photophobia, headaches and excessive lacrimation.

The decrease in the blink rate induced by the use of computers is associated with the attention and fatigue levels necessary to perform the tasks and results in the aggravation of the dry eye symptoms in predisposed people. The high variability levels of the blinking patterns may represent a relevance factor to explain the relationship between the computer use and the ocular/visual system ${ }^{(14-16)}$.

No data about the time between blinks in different age groups and visual activities was found in the published literature.

This study aimed at investigating the time between blinks in young adults and in presbyopic adults, during conversation and VDT reading situations.

\section{METHODS}

A transversal study in a readily accessible sample consisting of employees from Volkswagen do Brasil - Curitiba, Paraná, was performed. The cohort group consisted of 108 subjects divided into two age groups: Group 1, the young adult group (age range 20-39): 77 employees, mean age of 30.09 \pm 5.09; Group 2, the presbyopic adult group, (age range 40-53): 31 employees, mean age of $44.17 \pm 3.00$. All subjects were examined in the same day under the same working conditions. The study excluded subjects under 18 years of age, those who had a history of ocular disorders, contact lens wearers and computer non-users. The cohort was selected by means of a survey and eye examination was performed in the employees' indoor work environment.

The characterization of the indoor environment included illuminance levels, temperature, air speed and relative humidity. Although subjects had been advised that they would be filmed during the reading on VDT and conversation activities for research purposes, further details were not provided. The monitors used were 14" CRT Samsung, resolution of 800X600 Megapixels, provided by the company. Activity on VDT consisted of reading the same piece of text, for 13 minutes. For the interview, specific questions helped subjects engage in conversation. All subjects of both groups had their faces filmed for 10 minutes (600 seconds), in conversation and VDT reading situations. The filming was carried out in the employees' own indoor work environment, by six well-trained people, using each a Sony Handycam DCR-HC30, set on its tripod.

The mean time between blinks was calculated in seconds and fractions of a second by means of a software program specially designed for this study. As a dispersion measure, the standard deviation was selected. The determination of each blink happened in slow motion from the point where the upper eyelid movement started.

To compare the quantitative variables the 8.0 Statistics software was used.

Four comparison analysis were performed:

Comparison 1 - Time between blinks in conversation and VDT reading situations in Group 1.

Comparison 2 - Time between blinks in conversation and VDT reading situations in Group 2.

Comparison 3 - Time between blinks in conversation situations between Groups 1 and 2 .

Comparison 4 - Time between blinks in VDT reading situations between Groups 1 and 2 .

To perform the descriptive statistical analysis, the Student's $t$-test was used revealing a significance level of 95\%.

The present study was approved by the Ethical Commission in Research of the Universidade de São Paulo under the number 1068/07.

\section{RESULTS}

The VDT users were studied in their indoor work environment. The average illuminance level, temperature, air speed and relative humidity were $288 \mathrm{lux}, 21.1^{\circ} \mathrm{C}, 0.032 \mathrm{~m} / \mathrm{s}$ and $52.8 \%$, respectively.

Graph 1 shows the average blinking time of all subjects involved in this study, young adults and adults in the presbyopic age group, in conversation and VDT use. 


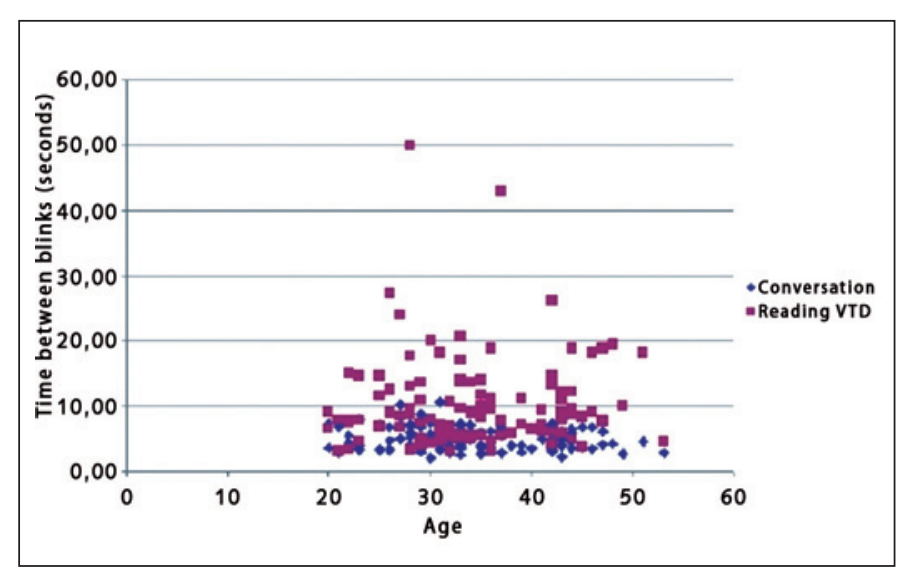

Graph 1 - Average blinking time of all young adults and adults in the presbyopic age group, in conversation and VTD reading situation

For Group 1, in conversation situations, the time between blinks ranged from 1.99 to 10.71 , a mean of $5.16 \pm 1.83$ seconds (11.62 blinks/minute) (Table 1 and 2); in VDT use it ranged from 3.11 to 50.00 , a mean of $10.42 \pm 7.78$ seconds $(5.75$ blinks/ minute) (Table 1 and 2).

For Group 2, in conversation situations, the time between blinks ranged from 2.17 to 8.00 , a mean of $4.90 \pm 1.49$ seconds (12.24 blinks/minute) (Table 1 and 2); in VDT use situations, it ranged from 3.82 to 26.09 , a mean of $10.46 \pm 5.54$ seconds (5.73 blinks/minute) (Table 1 and 2).

Comparison 1 - Group 1 (young adults) time between blinks in conversation and VDT reading situations: there was a significant statistical difference $(\mathrm{p}<0.0001)$. The $95 \%$ confidence interval ranged from 3.4605 to 7.0595 (Table 1). The blinking rate decreased 2.02 times during VDT reading when compared to conversation situations.

Comparison 2 - Group 2 (presbyopic adults) time between blinks in conversation and VDT reading situations: there was a significant statistical difference $(\mathrm{p}<0.0001)$. The $95 \%$ confidence interval ranged from 2.9029 to 8.2171 (Table1). The blinking rate decreased 2.13 times during VDT reading when compared to conversation situations.

Comparison 3 - the time between blinks in conversation situations between Groups 1 (young adults) and 2 (presbyopic adults): the obtained difference was not statistically significant $(\mathrm{p}=0.4840)$ (Table 2).

Comparison 4 - the time between blinks in VDT reading situation between Group 1 (young adults) and Group 2 (presbyopic adults): the difference was not statistically significant $(\mathrm{p}=0.9793)$ (Table 2).

\section{DISCUSSION}

Man in his evolution stopped his hunting activities and has increasingly undertaken intellectual work within indoor environments. The use of computers has represented, in a few years, the most important revolution in the professional acti- vities performed by human beings. The visual alterations caused by the use of computer are mainly due to the alterations in the blink rate induced by the attention level observed in these $\operatorname{activities}^{(17)}$.

This study showed a meaningful increase in the time between blinks during VDT reading when compared to conversation situations, both in the young adult and presbyopic adult groups. This finding can be accounted for by the inhibition of the spontaneous blinking in the motor cortex induced by the attention level in VDT situations ${ }^{(18-20)}$. Blinking frequency in young adults and presbyopic adults decreased 2.02 times and 2.13 times, respectively, during VDT reading when compared to conversation situations. The decrease in blinking frequency during VDT situations corroborates the findings published in the researched literature ${ }^{(21-23)}$.

Hence, it is crucial to establish an ergo-ophthalmologic planning in the work environment with the objective to minimize the impact of the occupational activity on the visual performance. Factors such as air speed, temperature, humidity, lighting and computer screen positioning must be controlled to achieve improvement in the tear film and consequently in the quality of professional life (QPL) ${ }^{(12,23)}$.

In conversation situations, for Group 1 , the time between blinks ranged from 1.99 to 10.71 , a mean of $5.16 \pm 1.83$ seconds (11.62 blinks/minute); and for Group 2, it ranged from 2.17 to 8.00 , a mean of $4.90 \pm 1.49$ seconds (12.24 blinks/minute). This finding corroborates the values encountered in the researched literature, which presents the blinking frequency in conversation situations between 10 and 20 blinks per minute ${ }^{(22-24)}$.

The time between blinks in conversation and VDT reading situations between Group 1 and Group 2 was not statistically significant ( $\mathrm{p}=0.4840$ and $\mathrm{p}=0.9793$, respectively).

One of the limitations of this study is the cohort maximum age of 53. The authors suggest that further research on similar indoor environment situations should include older cohorts to corroborate their findings.

\section{CONCLUSION}

The time between blinks in young adults and in presbyopic adults decreased in VDT reading when compared to conversation situations. There was no statistically significant difference in the blinking time between the two groups, in conversation and VDT reading situations.

The relationship between work and vision is a promising field of research which must be stimulated to provide better understanding about the multiple complaints of computer users, and thus, offer them adequate solutions.

\section{RESUMO}

Objetivos: Investigar o intervalo entre as piscadas em adultos jovens e em présbitas, durante conversação e leitura no monitor do computador. Métodos: Realizou-se estudo transver- 
Table 1. Young adult and presbyopic adult average blinking time in conversation and VDT reading situations

\begin{tabular}{|c|c|c|c|c|c|c|}
\hline \multirow[b]{2}{*}{$\begin{array}{l}\text { Time between } \\
\text { blinks }\end{array}$} & \multicolumn{2}{|c|}{ Young adults } & \multirow{2}{*}{$\begin{array}{l}\text { Student's } \\
\text { t-test }\end{array}$} & \multicolumn{2}{|c|}{ Presbyopic adult } & \multirow{2}{*}{$\begin{array}{c}\text { Student's } \\
\text { t-test }\end{array}$} \\
\hline & In conversation & In VDT reading & & In conversation & In VDT reading & \\
\hline Minimum & 1.99 & 3.11 & & 2.17 & 3.82 & \\
\hline Maximum & 10.71 & 50.00 & & 8.00 & 26.09 & \\
\hline Mean & $5.16 \pm 1.83$ & $10.42 \pm 7.78$ & $p<0.05$ & $4.90 \pm 1.49$ & $10.46 \pm 5.54$ & $p<0.05$ \\
\hline
\end{tabular}

\begin{tabular}{|c|c|c|c|c|c|c|}
\hline \multirow[b]{2}{*}{$\begin{array}{l}\text { Time between } \\
\text { blinks }\end{array}$} & \multicolumn{2}{|c|}{ In conversation } & \multirow{2}{*}{$\begin{array}{c}\text { Student's } \\
\text { t-test }\end{array}$} & \multicolumn{2}{|c|}{ VDT reading } & \multirow{2}{*}{$\begin{array}{c}\text { Student's } \\
\text { t-test }\end{array}$} \\
\hline & Young adult & Presbyopic adult & & Young adult & Presbyopic adult & \\
\hline Minimum & 1.99 & 2.17 & & 3.11 & 3.82 & \\
\hline Maximum & 10.71 & 8.00 & & 50.00 & 26.09 & \\
\hline Mean & $5.16 \pm 1.83$ & $4.90 \pm 1.49$ & $p<0.05$ & $10.42 \pm 7.78$ & $10.46 \pm 5.54$ & $p<0.05$ \\
\hline
\end{tabular}

sal, analítico, em amostra prontamente acessível, composta por funcionários da Volkswagen do Brasil, em Curitiba (Paraná-Brasil). A amostra foi dividida em dois grupos de acordo com a idade: grupo 1 (20-39 anos); grupo 2 (40-53 anos). Foram excluídos menores de 18 anos, portadores de doenças oculares, usuários de lentes de contato e não usuários de computador. Os participantes tiveram suas faces filmadas por $10 \mathrm{minu}-$ tos durante atividades de conversação e leitura no monitor do computador. Utilizou-se teste t de Student, com nível de significância de 95\%. Resultados: A amostra compôs-se de 108 indivíduos, sendo o grupo 1 com 77 indivíduos, com idade média $30,09 \pm 5,09$ anos e grupo 2 com 31 indivíduos, com idade média 44,17 $\pm 3,00$ anos. O tempo médio entre as piscadas, no grupo 1 , em conversação foi de $5,16 \pm 1,83$ e leitura no monitor de 10,42 \pm 7,78 segundos; no grupo 2 , em conversação foi de $4,90 \pm 1,49$ e leitura no monitor de 10,46 $\pm 5,54$ segundos. Encontrou-se distância maior entre as piscadas, durante a leitura no monitor $(p<0,0001)$ nos dois grupos etários. Conferindo os resultados encontrados nos dois grupos, nas situações de conversação e leitura no monitor, não houve diferença estatisticamente significativa ( $p>0,05)$. Conclusão: Houve um aumento no intervalo entre as piscadas, em adultos jovens e em présbitas, durante a leitura em monitor quando comparada com situação de conversação. Não se evidenciou diferença estatisticamente significativa entre os participantes dos dois grupos, nas situações de conversação e leitura no monitor.

Descritores: Terminais de computador/utilização; Piscadela; Presbiopia; Adolescente; Adulto

\section{REFERÊNCIAS}

1. Bron AJ, Tiffany JM, Gouveia SM, Yokoi N, Voon LW. Functional aspects of the tear film lipid layer. Exp Eye Res. 2004;78(3):347-60.
2. Carney LG; Hill RM. The nature of normal blinking patterns. Acta Ophthalmol. 1982;60:427-33.

3. Lavezzo MM; Schellini AS; Padovani CR. Avaliação comparativa do ritmo de piscar em crianças normais em idade pré-escolar. Arq. Bras. Oftalmol. 2007;70: 481-486.

4. Dumery B, Toi VV. Relationship between blink rate, ocular discomfort and visual tasks [abstract]. Invest Ophthalmol Vis Sci. 1997;38(S):68.

5. Takahagi RU, Gonçalves F, Yamamoto RK, Viveiros MMH, Schellini AS, Padovani CR. Ritmo de piscar em portadores de pterígio antes e após a exérese. Arq. Bras. Oftalmol. 2008;71: 381-384.

6. Kara-José N; Rangel FF; Panetta H; Barbosa NLM. Alterações corneanas devidas a oclusão palpebral incompleta durante o sono. Rev Bras Oftalmol. Rio de Janeiro, 2008;39:37-48.

7. Barbato G, Ficca G, Muscettola G, Fichele M, Beatrice M, Rinaldi F. Diurnal variation in spontaneous eye blink rate. Psychiatry Res. 2000;93(2):145-51.

8. Bentivoglio AR, Bressman SB, Cassetta D, Carretta D, Tonali P, Albanese A. Analysis of blink rate patterns in normal subjects. Mov Disord. 1997;12(6): 1028-34.

9. Sahlin S, Chen E. Gravity, blink rate and lacrimal drainage capacity. Am J Ophthalmol. 1997;124(6):758-64. Comment in: Am J Ophthalmol. 1998;126(1): 152.

10. Tsubota K, Toda I, Nakamori K. Poor illumination, VDTs, and desiccated eyes. Lancet. 1996;347(9003):768-9.

11. Reijula K, Sundman-Digert C. Assessment of indoor air problems at work with a questionnaire. Occup Environ Med. 2004;61(1):33-8.

12. Wolkoff P, Nojgaard JK, Troiano P, Piccoli B. Eye complaints in the office environment: precorneal tear film integrity influenced by eye blinking efficiency. Occup Environ Med. 2005;62(1):4-12.

13. Piccoli B. A critical appraisal of current knowledge and future directions of ergophthalmology: consensus document of the ICOH Committee on 'Work and Vision'. Ergonomics. 2003;46(4):384-406.

14. Stern JA. Blink rate: a possible measure of fatigue. Human Factors. 1994;36: 285-97.

15. Tsubota K. Tear dynamics and dry eye. Prog Retin Eye Res. 1998;17(4):565-96.

16. Fenga C, Aragona P, Cacciola A, Cacciola A, Spinella R, Di Nola C, et al. Meibomian gland dysfunction and ocular discomfort in video display terminal workers. Eye. 2008;22(1):91-5.

17. Ponder E, Kennedy WP. On the act of blinking. QJ Exp Physiol. 1927;18(2): 89-110.

18. Stern JA, Walrath LC, Goldstein R. The endogenous eyeblink. Psychophysiology. 1984;21:22-33.

19. De Gennaro L, Devoto A, Lucidi F, Violani C. Oculomotor changes are associated to daytime sleepiness in the multiple sleep latency test. J Sleep Res. 2005;14(2):107-12.

20. Gehricke JG, Ornitz EM, Siddarth P. Differentiating between reflex and spontaneous blinks using simultaneous recording of the orbicularis oculi elec- 
tromyogram and the electro-oculogram in startle research. Int J Psychophysiol. 2002;44(3):261-8.

21. Kaneko K, Mito K, Makabe H, Takanokura M, Sakamoto K. Cortical potentials associated with voluntary reflex, and spontaneous blinks as bilateral simultaneous eyelid movement. Electromyogr Clin Neurophysiol. 2004;44(8):455-62.

22. Doughty MJ. Consideration of three types of spontaneous eyeblink activity in normal humans: during reading and video display terminal use, in primary gaze, and while in conversation. Optom Vis Sci. 2001;78(10):712-25.

23. Davson, H. The protective mechanisms. In: Davson H. The physiology of the Eye. $3^{\text {th }}$ ed. Edinburgh: Churill Livingstone; 1972. p.416.

24. Moses RA. The eyelids. In: Adler FH, Moses RA, Hart WM. Adler's physiology the eye: 1 application. $8^{\text {th }}$ ed. St Louis: Mosby; 1987. p.8. 